【結果・考察】シミュレーションで得られた三次元画像により, 水中 に拈ける線源からの放出光子の挙動が視覚的に確認できた．また水 中におけるエネルギー損失の分布図も得られ，今後は現行の線量計 算ソフトとの線量分布の比較が課題である.

316 婦人科領域の腔内照射における重要蔵器線量低隇の工夫 滋賀医科大学 綱 裕人, 本多恵理子, 井口治巳, 野間和夫 橋本恵次, 近藤康雄, 増田一孝

【目的】当院では192Ir高線量率腔内照射治療時(婦人科領域)には, 毎 回CT撮影を実施し, ターゲットおよびリスク臓器 (直腸, 膀胱)の線 量評価を行っている. 今回, 婦人科領域 (胵断端部一外陰部) 治療時 に扔いて,リスク臓器の線量低減 (主に直腸線量)を目的に, 臸アプ リケータ 2 種(1ツ穴および2ツ穴)にそれぞれスペーサを装着し， ターゲットおよびリスク臟器の線量評価を行った。

【方法】症例 1 -臸中央部〜外陰部 (1 ツ穴アプリケータ), 症例 2 胵断端部一外陰部(2ツ穴アプリケー夕)において，スペーサ装着無 しおよびスペーサを目的臟器側に装着した時の, ターゲットおよび リスク臟器線量の比較検討を行った。なお，それぞれの症例は，治 療回数 4 回の内 2 回をスペーサ装着とした。また, 線量評価はそれ ぞれの治療開始前に取得したCT画像を用いて行った。

【結果】症例 1 では, 直腸線量最大値 ( 2 回平均)で $26 \%$ の低減となり, 症例 2 では, 直腸線量最大值 ( 2 回平均) で $32 \%$ の低減となった。 な お, ターゲット線量においては, 両症例とも約 $5 \%$ 程度低隇する部 分が生じた.また, 両症例とも直腸線量のDose Volume Histogramに よる比較においても，その有意差が確認された。

【考察】192Ir高線量率腔内照射, 婦人科領域治療においては, 重要臓 器障害を減らすために, 目的重要臟器側にスペーサを装着すること は有効であり,また, リスク臓器の線量評価に, CT撮影は必須であ ると考える.ターゲット線量における線量低減部分については, 治 療開始前に治療効果に与える影響について放射線治療医との検討が 必要と考える。

\section{$317{ }^{60} \mathrm{Co}$ 密封小線源の線源近傍の深部線量}

福岡大学病院·放射線部 長松健一, 吉川治雄, 田中 稔

澤田登美子，上田嘉郁，稲富孝治

九州大学・医学部保健学科 上原周三

【目的】外照射に用いられる ${ }^{60} \mathrm{Co}$ の深部線量曲線は平行線束照射下に おいて $0.5 \mathrm{~cm}$ の位置にピークをもつ. しかし， ${ }^{60} \mathrm{Co}$ 密封小線源の場合 は平行線束ではないビームを放出する. 今回, ${ }^{60} \mathrm{Co}$ 密封小線源近傍 に扮ける深部線量曲線を検証した。

【使用機器】 ${ }^{60} \mathrm{Co} /{ }^{192} \mathrm{Ir}$ 線源選択型りモートアフターローディングシス テムmulti source(ドイツ STS社製)，線源60 Co (67.6GBq 2002.12.5)， 形状 直径0.6mm 長さ3.5mmの線状, UNIDOS chamber TYPE31006 $0.15 \mathrm{cc}$ (PTW社)，水ファントムMP3(PTW社)

【方法】1. 水中での実測における相対線量測定と同一条件下でのモン テカルロシミュレーション線量計算 ピンポイントチェンバーを使 用し, 線源中心を 0 として線源に最も近づく位置から $1 \mathrm{~cm}$ までを $1 \mathrm{~mm}$ 間隔で， $8 \mathrm{~cm}$ までを $5 \mathrm{~mm}$ 間隔で測定し線量減弱曲線を測定し た。また計算コードMCEP(九州大学上原)を用いて同一条件下で計 算を行った． 2. 入射角の違いによるモンテカルロシミュレーション 線量計算 線源から測定点に対して入射角度を一 90 度から 90 度まで 拡げて, モンテカルロシミュレーションによる線量計算を行った。 【結果】1、実測值とモンテカルロシミュレーションによる計算值の線 量曲線にほぼ差異はない．2. ビームの入射角度が拡がるにつれピー クが線源側に近づく.

【結論】 ${ }^{60} \mathrm{Co}$ 密封小線源での深部線量曲線は線源近傍でビルドアップ は認められない，したがって， ${ }^{60} \mathrm{Co}$ 密封小線源を利用する放射線治 療に扔いて線源の近傍においても線量不足にならないことを示して
いる.

318 簡易測定ファントムと反射型フィルムを利用したI-125 Seed 線源のQA/QC

徳島大学・医学部保健学科 笈田将皇，八木浩史

徳島大学病院・診療支援部佐々木幹治，富永正英，原康夫 徳島大学・医学部放射線科 西谷 弘

【目的】近年，I-125 Seedによる前立腺がん小線源治療が普及しつつあ る.今回，我々はファントムを作製し，反射型フィルムを利用した 線源強度の検出精度改善を試みたので報告する。

【方法】反射型フィルムは，GAFCHROMIC-Film RTQAを使用した。 同一検定日のI-125線源 (約 $11 \mathrm{MBq}$ ) 11個をアクリルファントム (自作) 内に配置し，フィルムに近接させて一定時間 [60分を基準，54分(10\%)，63分(+5\%)]照射した. その後, フィルム解析システム $(\mathrm{DD}-$ System)により青色デジタルフィルタを通して照射直後と24時間後に フィルムをスキャンした。フィルム解析から線源近傍に関心領域 (ROI) を設定し，平均ADC(Analog-Digital Conversion)值を得た。照 射時間，ROIの大きさ $(5 \sim 100$ pixel円 $)$ ，照射経過時間，ADC值につ いて統計解析を行い, 最適なデー夕取得パラメータを探索した.

【結果】平均 $\mathrm{ADC}$ 值はROIの大きさ, 線源強度, 照射時間に依存して 経時的に変化した． 24 時間後の值は照射直後に比べて $0.7 \sim 1.8 \%$ 増加 した. ROIを小さくするにつれて平均ADC值の上昇，変動幅の増大 がみられるが，線源と同等のROI (40～60pixel)を設定することで良 好な検出精度が得られた。基準照射群に対し，-10\%，+5\%の照射 群では有意に差を検出できた $(\mathrm{p}<0.05)$ ．また， $-10 \%$ 照射群では高 感度で強度の違いを検出できた。

【結論】反射型フィルムを利用した線量測定では, 経時的変化, ス キャナ，フィルム特性の影響を考虑しなければならないが，10\%を 超える線源強度の違いは有意に鑑別可能であった.ファントムの作 製により，簢便かつ安定した精度でI-125 SeedのQA/QCを行うこと が可能となった.

319 CRT-GOS (Conformal Radiation Therapy with Gravity Oriented Shield)法による線量分布の基礎的検討

黒部市民病院・中央放射線科 松嶋正則，下田政儀，米田 剛 米沢辰男

金沢大学大学院. 医学系研究科 田中利恵, 菊池雄三 岐皁医療技術短期大学・診療放射線技術学科 内山幸男

【目的】椎体など馬蹄状の病巣に対する照射法として, IMRTに代わ り，MLCを用いた打ち抜き原体照射法(CRT-GOS法)が用いられてい る.この方法は, 打ち抜き吸収体を使用せずに原体の線量分布が得 られる簡便な照射法である反面, 高線量域の増加や専用ソフトウ工 アの採用などの問題もある. 本研究では, 線量分布の改善を目的と してCRT-GOS法にPhysical Wedgeを併用し, 各照射術式と比較, そ の有用性を検討した.

【方法】模擬計画として, CRT-GOS法の360回転(Arc) と固定20門 ウェッジなし (open), あり $\left(\mathrm{W} 15^{\circ}, \mathrm{W} 30^{\circ}, \mathrm{W} 45^{\circ}, \mathrm{W} 60^{\circ}\right)$ の 6 プラン をRTPs (Varian社製 Eclipse)で計画した。リニアック(Varian社製 Clinac2100C)X線10MVを水等価ファントム (Gammex社製 Solid Water)に照射し，フィルム法による測定を行った．線量分布の解析 はフィルム線量解析システムRIT113(日本バイナリー)を用いた. 90 \%から $105 \%$ の等線量曲線の画像データからフリーソフトを用い面 積を測定し, 治療計画に対する一致率・過小率・過大率, PTVのカ バー率を評価した。

【結果】1)V95のDVHはArcとW60齐良好であり，特にW60では高線 量域の体積が減少した．2） $90 \%$ 等線量曲線では $92 \%$ 以上の一致率, $8 \%$ 以内の過小率, $5 \%$ 以内の過大率, $95 \%$ 以上のカバー率であっ た. 3) $105 \%$ 等線量曲線のカバー率はopenが大きく, W60゙最も小 
さかった。

【考察・結語】椎体などに対する照射法として，W60索使用した CRT-GOS法は高線量域の抑制に有用であると考える、今後，Arc， ウェッジ，荷重などを組み合せた，より簡便で至適な線量分布を有 する照射技術の改良を検討する。

\section{0 腹臥位用全脳全脊娟照射固定具の作成}

東京女子医科大学・放射線腫瘍部 大野 淳, 福岡美代子，稲並臣哉 五家小百合, 土橋浩之，黒岡将彦，羽生裕二

【目的】当院では全脳全春䯣照射において全身吸引バキュームを用い 腹臥位で行うことにより, 細長い照射野に春髄を確保する位置精度 や簡便性を向上させてきた。しかしながら治療中の体位を保持する には息苦しさなど患者の負担が大きくなるデメリットが生じてしま う。これを改善する目的で当院にて使用していた腹臥位用固定具を 改良したので報告する。

【方法】照射方法は従来通り全脳左右対向二門，脊髄は上下二つに分 けてSSD法後一門, 総照射期間中につなぎ目を 3 回変更して行う. ポジショニングはライナック寝台の上に厚さ $5 \mathrm{~cm} \times$ 幅 $50 \times$ 長さ $200 \mathrm{~cm}$ 硬質スチロール，40×180cm全身吸引バキューム，頭部シェル固定プ レート， $15 \times 30 \mathrm{~cm}$ 吸引フェイスバキューム (エンジニアリングシステ ム)の順に設置し, 患者を腹臥位にて固定する. 従来と異なる点は呼 吸と視野が快適になるよう顔下に空間を確保するため, 上記固定具 の顔面部分に20×20 cm〜 $10 \times 10 \mathrm{~cm}$ 程度の空洞を設けた。

【結果】従来使用の腹臥位用固定具に比べ, 吸引フェイスバキューム を使用することで固定具作成時間が短縮し, 顔下の空間により寝台 マイラー部分から床下までの視野を確保したことで圧迫感や閉塞 感, 息苦しさなどを改善でき照射中の患者負担を軽減させることが 可能となった.

【まとめ】腹臥位の状態で通常呼吸が可能で, 体位が楽に保持できる ことで照射中の動きを抑えることができ，線量分布つなぎ目の再現 性も向上すると考える。また, 寝台マイラー部分から床まで約 $120 \mathrm{~cm}$ の視野空間を確保できたので, 小児患者においても床上に ノートPCを用いてDVDビデオを見ながらの照射が可能である.

321 直線加速器のフォールトトレランス

信州大学医学部附属病院・放射線部 前島 偉，小口宏 松田多美子，芹澤陽一

【目的】治療装置のトラブルによる放射線治療の休止は, 治療期間の 延長を招き患者サービスの観点においても好ましくない．特に全身 X線照射や多分割加速照射, 定位照射における治療休止は治療効果 の低下や臨床面での問題を引き起こす。 そこで, 我々は直線加速器 の移転更新に伴い, 新旧 2 台の直線加速器によるフォールトトレラ ンスシステムを導入した，今回X線におけるビームマッチングの検 証結果を報告する。

【方法】直線加速器は同じヘッド構造であるVarian社製 Clinac-2100C (1 号機) とClinac-21EX(2号機)であり, いずれも $4 \mathrm{MV}, 10 \mathrm{MV} の \mathrm{X}$ 線を有している. 相互の加速器は, 基準条件での深部量百分率半価 深を指標として 2 号機を 1 号機に0.3mm以内で一致させるように ビームコミッショニングを行った。検証は組織最大線量比, 線量プ ロファイル, 出力係数, 線量分布 (ファントム, 臨床例), 治療計画 装置(Varian社製Eclipse) とマニュアル計算によるMU值より行った。

【結果】 1 号機, 2 号機各々のTMRの差は $\pm 0.4 \%$, 出力係数は $\pm 0.2 \%$ となり, その他の諸係数, 平坦度のBeam Profile等は約 $1 \%$ 程度の 差となった. 線量分布はファントム, 臨床例ともにほぼ一致し大き な差分は認められなかった. 最終的なMU值は治療計画装置, マ ニュアル計算ともに 1 \%以内になり良好な結果であった。これによ り, 相互の加速器は同等の性能で, フォールトトレランスを行うの に必要な整合性がとれたと判断した。臨床の運用面では, 加速器の
代替え照射が行える放射線治療情報システムで，ストレスのない ワークフローを実現している。

\section{2 新しい遮蔽材を用いた電子線の遮蔽における照射野内への影} 響

放射線医学総合研究所重粒子医科学センタ一病院・診療放射線技師室 田尻 稔, 铇矢祐治, 砂岡正良

【目的】鉛は，最近公害の原因の一つと考えられている。そこで鉛を 含有していない樹脂とタングステンから成る新しい遮蔽材りを入手 したので，電子線遮蔽における照射野内への影響を検討した。電子 線に対して不整形照射野を形成する際，その遮蔽材から発生する2 次放射線の照射野内への影響について考慮しなければならない。そ こで, 元来, 装置に付属している電子線コリメー夕(以下, readymade) と, 新しい遮蔽材を ready-made と同形状に加工したコリメータ (以下, hand-made) 加発生する 2 次放射線を比較検討する.

【方法】ready-made と同形状のhand-madeを用いて深部量百分率 (PDD), beam profile (平坦度, 対称性, 半影, 最大線量比)を比較す る. beam profileは標準測定深, 及び基底深にて測定する。電子線の エネルギーは6-, 9-, 12-, 20-MeVを用いた。

【結論】両者を比較するとPDDは土1％以内で一致し, beam profileに ついてもIEC等の規格以内におさまっている．今回の結果から，こ の新しい遮蔽材が電子線でも使用可能であると考える.

【参考文献】1) Minoru Tajiri, Masayoshi Sunaoka, Akifumi Fukumura and Masahiro Endo: A new radiation shielding block material for radiation therapy. Med Phys., 31, 3022-3023, (2004).

323 患者呼吸模擬システムを用いた線量分布の検証(1)計画線量 分布と実線量分布の比較

国立がんセンタ一東病院・放射線部 遠山尚紀，大山正哉，井上一雅 伍賀友紀，福原里恵

埼玉医科大学総合医療センター・中央放射線部 新保宗史

国立がんセンター東病院・陽子線治療部 荻野 尚

首都大学東京・健康福祉学部 齋藤秀敏

【目的】現在，放射線治療は，3次元から呼吸同期，動態追跡などを 利用し時間軸を加えた 4 次元へと変わりつつある。しかし，これら の手法はすべての治療で行われているわけではなく，依然として3D 放射線治療が一般的である，時間軸を考慮していないため，治療計 画装置による計算線量分布と実際の線量分布には差異が存在する。 そこで, 患者呼吸模擬システムを開発し, 肺腫瘍を模擬したファン トムを用いて計算線量分布と実線量分布の比較・検討を行った.

【方法】我々が開発した患者呼吸模擬システムに肺を模擬したコルク 内に腫湯として直径 $3 \mathrm{~cm}$ の球が挿入されたファントムを乗せ実際の 呼吸の動きを模擬した。呼吸波形は当施設陽子線治療での呼吸同期 波形を用いた。線量分布は，Pinpoint Chamberを用いた腫瘍中心線 量, EDR2を用いた線量分布での比較, 検討を行った.

【結果】呼吸による内部マージンを考慮し照射野を決定した場合，腫 瘍中心線量は計画線量と大きな差は生じなかった。しかし, 照射さ れる範囲は計画された範囲より広範となった。詳細は学会で報告す る。

【考察】結果から治療部位を肺とした場合，治療計画装置はV20を過 小評価していることが示唆された。また，線量計算で使用する治療 計画CTは撮影方法を十分に吟味する必要がある。 